\begin{tabular}{|c|c|c|}
\hline $\begin{array}{l}\text { FATIH } \\
\text { SULTAN } \\
\text { MEHMET } \\
\text { VAKK UNIIVERSIESI } \\
2010\end{array}$ & $\begin{array}{l}\text { FSM İlmî Araştırmalar Insan ve Toplum Bilimleri Dergisi } \\
\text { FSM Scholarly Studies Journal of Humanities and Social Sciences } \\
\text { Sayı/Number } 15 \text { Yıl/Year } 2020 \text { Bahar/Spring } \\
\text { (C2020 Fatih Sultan Mehmet Vakıf Üniversitesi }\end{array}$ & 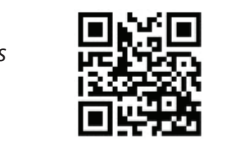 \\
\hline DOI: & http://dergipark.org.tr/fsmia & http://dergi.fsm.edu.tr \\
\hline Araştırma Makalesi / Research Article & Geliş Tarihi / Received: 09.03.2020 Kabul Tarihi / Accepted: 04.05.2020 & FSMIAD, 2020; (15): 459-476 \\
\hline
\end{tabular}

\title{
Geleneksel Sanatlarımızdaki Bitkisel Kompozisyonların Temeli Olan Helezonların Tarihçesi ${ }^{*}$ Hamide Nur Özsoy ${ }^{* *}$
}

\section{$\ddot{O} \mathbf{z}$}

Kainattaki herşey oran ve orantı sistemleri üzerine yaratılmıştır. Bir çok varlığın yapısında bulunan helezonlar da bu oransal harmoniyi barındırarak oluşmuş sarmal biçimli yapılardır. Sanatçılar kâinattaki bu mükemmelliği yansıtmak istemiş ve İlahî Oranlar'1 eserlerinde uygulamaya çalışmışlardır. Yüzyıllardır farklı sanat dallarında kullanılan helezonlar geleneksel sanatlarımızdaki bitkisel kompozisyonların temelinde de yer almaktadır. Helezonların tarihçesi insanlık tarihi kadar eskidir. Sanatçılar tabiatı gözlemleyerek, sabır ve yetenekleriyle mükemmel tasarımlar oluşturmuşlardır. Kompozisyonların kusursuzluğu kullanılan oranlara bağlıdır. Sanatçılar bu uyum ve dengeyi helezonlarla sağlamışlardır. Makalemizde, geleneksel sanatlarımızda kullanılan bitkisel kompozisyonların temel taşını oluşturan helezonların tarihçesine 1şı tutmaya çalışılacaktır.

Anahtar Kelimeler: Geleneksel sanatlar, helezon, motif, kompozisyon.

\footnotetext{
* Bu çalışma Fatih Sultan Mehmet Vakıf Üniversitesi Lisansüstü Eğitim Enstitüsü Geleneksel Türk Sanatları Anasanat Dalında sürdürülen "Geleneksel Sanatlarda Kullanılan Bitkisel Motiflerin Tarihçesi” isimli sanatta yeterlik tez çalışmasından türetilmiştir.

** Sanatta Yeterlik Öğrencisi, Fatih Sultan Mehmet Vakıf Üniversitesi Lisansüstü Eğitim Enstitüsü, İstanbul/Türkiye, hamidenur.ozsoy@stu.fsm.edu.tr, ozsoy.nur@gmail.com, orcid. org/0000-0002-5471-5576
} 


\title{
The History of Spirals, the Foundation of Herbal Compositions, in our Traditional Arts
}

\begin{abstract}
Everything in the universe was created on proportion and proportion systems. Spirals which exist in the essenace of many entities are formed in spiral-shaped structures that contain such a proportinal harmony. The artists wanted to reflect this perfection in the universe and tried to apply the Divine Proportions in their works. Spirals, which have been used in different art branches for many centuries, also lies at the basis of floral compositions in our traditional arts. The history of spirals is as old as human history. The artists observed the nature and formed perfect designs with their patience and talent. The perfection of the compositions depends on the proportions used. The artists achieved this harmony and balance with spirals in their works. In our article, we will try to shed some light on the history of the spirals, which is supposed to be the cornerstone of floral compositions used in our traditional arts.
\end{abstract}

Keywords: Traditional arts, spiral, motif, composition 


\section{Giriş}

Kainattaki her şeyde, matematiksel bir oran, mükemmel geometriler ve sayısal boyutlar vardır. Bu İlahî oranlarla yaratılmış olan bir çok varlığın yapısında helezon karşımıza çıkar. Helezonlar yaşamımızın bir parçasıdır. Uzaydaki bir galaxinin şekli, küçük bir canlının kabuğu, bazı bitkilerin sürgünleri helezon biçimindedir. Süreklilik ve sonsuzluk hissi uyandıran büyüleyici tasarımlardır. Sanatçılar da bu mükemmelliği yakalamak istemiş ve bu İlâhî oranları kendi yapıtlarında uygulamaya çalışmışlardır. En eski medeniyetlerin günümüze ulaşan eserlerinde dahi bu uyum ve denge görülebilir.

Türkler, yüzy1llar boyunca bir çok toplumla irtibatta olmuş, çeşitli kültürlerle beslenip, farklı sanat üslûpları geliştirmişlerdir. Kendilerine ait kültür birikimlerini, farklı medeniyetlerin unsurlarıyla birleştirmiş ve sanat zevkleriyle diğer toplumları da yönlendirmişlerdir. Sanatımız yıllar içerisinde farklı kültürel öğelerin birikimiyle ilerlemiş ve geleneksel vasfı kazanmıştır. "Asırlar boyu gelenek ve göreneklerimizin olduğu kadar, din ve inançlarımızın etkisi altında gelişip, üslûplaşan el sanatlarımız zengin ve estetik bir yapıya sahiptir"'. Geleneksel sanatlarımızdaki kompozisyonlar belli oranlar ve dengeler üzerine kurulur ve bu uyumun temelinde helezonlar vardır.

Geleneksel sanatlarımızın kökeninin Orta Asya olduğu bilinmektedir. Türk sanatının temellerinin atıldığı Orta Asya bozkır sanatında hayvan üslûbunun yanında bitkisel tezyinat tarzı da gelişmiş̧ir. Kıvrık dal sistemi olarak bilinen bu bitkisel üslûbun kökeninde helezonlar vardır. Bu sanat tarzı İslâmiyetle beraber ilerlemiş ve geleneksel sanatlarda kullanılan kompozisyonlarda kullanılmaya devam etmiştir. Türkler tarih sahnesinde yer almaya başladıkları zamanlarda doğada bitkilerle iç içe göçebe bir hayat sürmüşlerdi. Bu hayat tarzlarını bitkileri gözlemleyerek, hayal güçleri ve yetenekleriyle birleştirerek günlük olarak kullandıkları hemen her eşyaya yansıtmışlardır. Bu nedenledir ki, geleneksel sanatlarımızda kullanılan bitkisel motifler çok geniş kapsamlı ve çeşitlidir. Hayatımızda büyük önem arz eden bitkiler sanatımıza da yansımış, geleneksel sanatlarımızın temelini oluşturmuşlardır. Başta lotus ve şakayık olmak üzere tabiattaki yüzlerce farklı türdeki çiçek birçok motifin kaynağıdır. Bitkiler, sadece çiçekleri ile değil, farklı yapılarıyla da esin kaynağı olmuşlardır. Çiçeklerin yaprak dizilimleri, dal sistemleri, eğrelti otları, sarmaşıklar, asma ve bir çok bitkinin sürgünleri, helezonlar şeklindedir. Bu yapılar kâinattaki mükemmel yaratılışın ve dengenin küçük birer örneği gibidirler. Geleneksel sanatlarımızdaki bitkisel kompozisyonlarda da tabiattaki kıvrımlar ve sarmal şekiller temel alınmıştır.

1 Cahide Keskiner, Türk Süsleme Sanatlarında Stilize Çiçekler-Hatayi, Ankara, T.C. Kültür Bakanlığ1, 2002, s. 1. 
Kâinattaki varlıkların yaratılışında var olan matematiksel oranlar uyum ve dengeyi sağlar. Gelenek sanatlarımızdaki kompozisyonlarda da bütünlük ve denge çok önemlidir. Bu uyumu oran ve orantı sistemi üzerine kurulu helezonlar sağlar. İlâhî oranların gözlemlenerek tasarımlara yansıtıldığg görülür. Kâinattaki oran sistemlerinde farklı helezon yapılara rastlanır. Bunlardan sanat alanında en çok kullanılanları Fibonacci ve Arşimet spiralleridir. Geleneksel sanatlarımızdaki kompozisyonlarda Arşimet spirali olarak bilinen yapılar örnek alınmıştır. Geçmişten günümüze bir çok farklı sanat dallarında kullanılmış olan ve bilinen ilk örnekleri milâttan önceki yüzyıllara dayanan helezonların tarihçesi insanların yeryüzündeki varlığı kadar eskidir.

Makalemizde, öncelikle helezonların yapısıyla ilgili bilgiler verilecek ve geleneksel sanatlarımızda kompozisyon başlığı altında helezonların bitkisel kompozisyonlardaki öneminden bahsedilecektir. Daha sonra, İslâmiyet öncesi ve İslâmiyet sonrası Türk sanatındaki helezonlara değinilerek örneklerle birlikte helezonların tarihçesi aydınlatılmaya çalışılacaktır.

\section{Helezon}

Helezon kelimesi kıvrımlı, sarmal anlamları taşımaktadır. Helezonun İngilizce sözlükteki Türkçe karşılı̆̆ spiral ve helix olarak karşımıza çıkar. Spiral kelimesi, helezonî sözcügünden alıntıdır². Bu nedenle helezon ve spiral kelimeleri birbirlerinin yerine kullanılabilmektedir. Helezonlar sarmal biçimli şekiller için kullanılır ve bu sarmal biçimler oran ve orantı üzerine kurulu sistemlerdir. Oran sistemiyle oluşturulan ve en sanatta en çok kullanılan helezonlar Fibonacci ve Arşimed spiralleridir.

Oran sistemlerinin kullanımı milâttan önceki dönemlere kadar uzanmaktadır. Oran sistemlerinden en fazla ilgi gören İlahî Oran olarak da isimlendirilen 1,618 rakamlarından oluşan altın orandır ${ }^{3}$. Mimarî, heykel, resim gibi pek çok sanat eserinin meydana getirilmesinde altın oranın rolü büyüktür. Milattan öncesine dayanan altın oran kullanımı Mezopotamya'dan eski Misır ve Yunanlara kadar uzanır ve Rönesans'ta doruğa ulaşmıştır. Phi sayısı olarak da adlandırılan 1,618 sayısı, küçük parçanın büyük parçaya oranı, büyük parçanın bütüne oranına eşit bölünmesi neticesinde çıkan sayısal değerdir. Bu sayı değeri insan anatomisinde, hayvanların yapısında, bitkilerin yaprak ve çiçeklerinde, doğadaki sayısız bir-

2 https://www.etimolojiturkce.com/kelime/spiral

3 Nihal Tekkanat, “Altın Oran'ın Kaynakları ve Sanat'a Yansıması”, (Yayımlanmamış Yüksek Lisans Tezi), Akdeniz Üniversitesi SBE, Grafik Anabilim Dalı, Antalya, 2006, s. 1. 
çok canlıda mevcuttur ${ }^{4}$. Altın oran ve Fibonacci sayıları arasında ilginç bir ilişki vardır. Fibonacci dizisi, her rakamın kendinden bir önceki rakamla toplanması sonucu ortaya çıkan dizidir. Fibonacci'de rakamlarının birbirlerine oranlanması sonucunda altın orana ulaşı1ır .

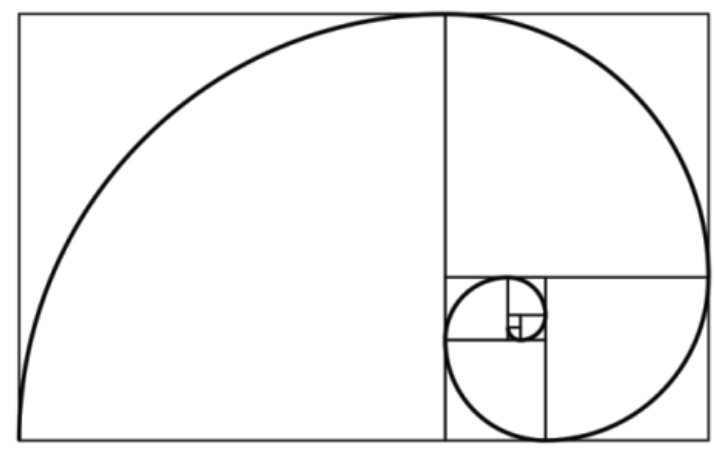

R. 1- Fibonacci Spirali

(https://tr.wikipedia.org/wiki/Dosya:Fibonacci_spiral_34.svg) (Erişim Tarihi:10.02.2020)

Kâinatta varlıkların yaratılışında diğer bir matematiksel oran ise Arşimed spirali olarak bilinir. Bu tip spiraller yani helezonlar, tezyînî sanatlarda en eski ve yaygın bir çizim şeklidir. Bu düzlem içindeki sabit bir nokta etrafında düzgün açıya sahip q hızıyla dönen bir ışın üzerinde, düzgün hareket eden bir noktanın geometrik yeridir. Burada her eğri kendisinden önceki ve sonraki eğrilere eşit uzaklıktadır. Bu ikinci tip spiraller yani helezonlar, tezyînî sanatlarda en eski ve yaygın bir çizim şeklidir ${ }^{6}$.

Helezonlar, insanlığın yeryüzündeki varlığından bu yana her medeniyet ve sanatta ortak kullanılan yapılar olmuşlardır. Geleneksel sanatlarımızın şekillenmesinde etkisi olan Çin, İran, Mezopotamya, Roma, Bizans ve Mısır gibi köklü mediyetlerde helezonlar sanatın vazgeçilmez unsurlarındandır. Türk sanatında da milâttan önceki yüzyıllardan bu yana oluşturulan bir çok desenin temelini oluştururlar.

4 Meryem Çiftçi, “XVI. Yüzyıl Kuran-1 Kerîm Sayfa Düzenleri Açısından Türk Tezhip Sanatında Altın Oran İncelemesi”, (Yayımlanmamış Yüksek Lisans Tezi), Fatih Sultan Mehmet Vakıf Üniversitesi Lisansüstü Eğitim Enstitüsü Geleneksel Türk Sanatları, İstanbul 2019, s. 1.

5 https://tr.wikipedia.org/wiki/Fibonacci_dizisi

6 İlhan Özkeçeci-Şule Bilge Özkeçeci, Türk Sanatında Tezhip, İstanbul, Seçil Ofset, 2007, s. 126-127. 


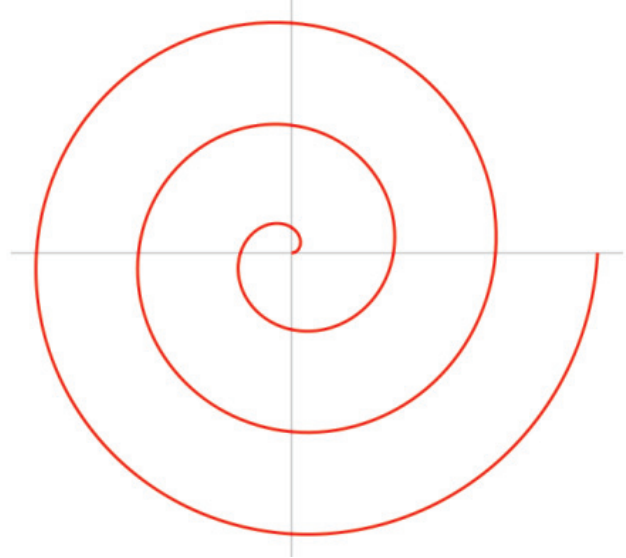

R. 2- Arşimet Spirali

(https://en.m.wikipedia.org/wiki/File:Archimedean_spiral.svg) (Erişim Tarihi: 10. 02. 2020)

\section{Geleneksel Sanatlarımızda Kompozisyon}

Geleneksel sanatlarımızda kompozisyon, motiflerin yüzeyler üzerine dengeli uyum içerisinde ve uygun bir tarzda yerleştirilmesidir ${ }^{7}$. Belli kurallarla yapılan kompozisyonlar, yüzyıllar öncesinden süregelen, içerisinde belli ölçüler barındıran sistemler bütünüdür. Ahşap, taş, cam, kâğıt, seramik, maden gibi birçok farklı yüzeye uygulanan desenlerde genel anlamda ortak olan belli kaideler olsa da, hepsinin birbirinden farklı ve eşsiz olması sanatımızın güçlü temeller üzerinde ilerlemesi ve sanatçıların yetenek ve bilgilerinin sonucudur.

Genel olarak klâsik desenlerde kullanılan planlar, bir noktadan çıkarak aynı yönde belli bir düzen halinde alana yayılan dairevî helezonlardan meydana gelir. Bu dağılım şekli desenin çeşidine uygun olarak farklı özellikler taşır. Çeşidi ne olursa olsun klâsik bir desenin planı çizilirken, helezonların yönü, düzeni ve çizgi yoğunluğu gibi dikkat edilecek ortak konular vardır. Desenin başlama noktasından çıkarak alan içine yayılan helezonların tıpkı tabiattaki bitkilerin dallarında görüldüğü gibi aynı yönde yayılarak devam etmesi önemlidir ${ }^{8}$.

7 Faruk Taşkale, “Tezhip Sanatının Kullanım Alanları”, (Yayımlanmamış Sanatta Yeterlik Tezi), Mimar Sinan Üniversitesi Sosyal Bilimler Enstitüsü Geleneksel Türk El Sanatları Anasanat Dalı Tezhip Programı, İstanbul, 1994, s. 48. 


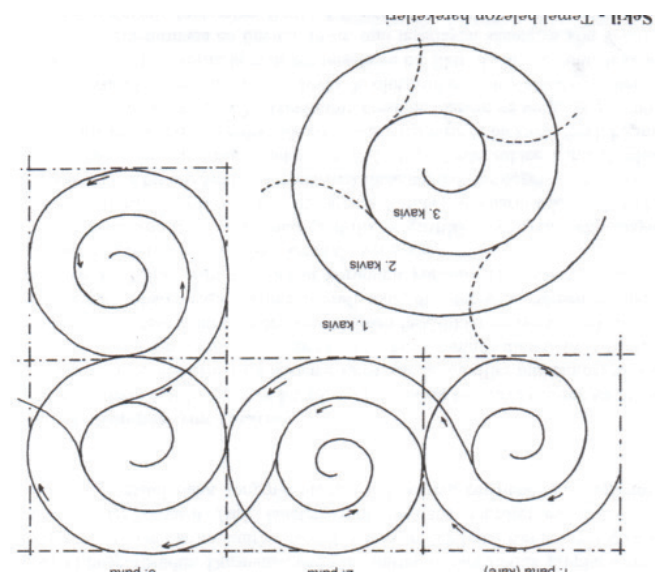

R. 3- Temel Helezon Hareketleri

(İlhan Özkeçeci-Şule Bilge Özkeçeci, a.g.e., s. 127)

Türkler kendilerine ait kültürel öğeleri, güçlü gözlem yeteneklerini ve yayıldıkları coğrafyalardaki medeniyetlerin sanatsal öğelerini birleştirmeyi başarmışlardır. Oluşturdukları kompozisyonlarda bu birikim göze çarpar. Sanatçılar tabiatı çok iyi gözlemiş ve bunu eserlerine en iyi şekilde yansıtmayı başarmışlardır. Geleneksel sanatlarımızdaki tasarımlarda matematiksel bir düzen ve uyum göze çarpar. Helezonların yönleri, boyutları ve kavislerin mesafelerinin eşit olması, motiflerin helezonlar üzerindeki dizilimi ve oranları çok önemlidir. Desenin çizileceği alanın büyüklüğüne göre helezonlar uygun boyutlarda yerleştirilir. Kompozisyonun oluşturulması için motifler helezonların üzerine belli yönlerde yerleştirilirler. Hatayî, penç ve yapraklarla oluşturulan tasarım tamamlanmış olur.

Desen hazırlanırken motifler, belirli bir teknik ve üslûp kullanılarak birleştirilmelidir. Türk sanatında, kırılmalar, düz çizgiler, keskin hatlar yerine kıvrımlı, yumuşak ve birbirleriyle uyumlu tasarımlar vardır. Sanat üslûbumuzun temelindeki ana çizgiler, tabiattaki bir çok varlığın yapısında yer alan unsurlardan biri olan helezonlardır. Helezonun çizim yönü, ya da büyüklüğü ne olursa olsun sonsuzluğu anlatır9. İnsanlığın yeryüzündeki varlığından itibaren dikkatlerini çekmiş ve bir çok sanat eserine esin kaynağ 1 olmuş bu sarmal yapılar, kâinattaki düzen ve uyumun küçük bir numunesi şeklindedir.

Kompozisyon düzenlemelerinde oranlar ve denge çok önemlidir. Tasarimlarda hem kompozisyonun bütünü, hem de parçaların birbirlerine oranlarında mükemmel dengeler kurulmuştur. Kaynağını tabiattan alan Türk sanatındaki kom-

9 Fatma Çiçek Derman, “Tezhip Sanatı”, İslâm Sanatları Tarihi, Eskişehir, Anadolu Üniversitesi Yayınlar1, 2012, s. 105. 
pozisyonların temelini helezon kavislerinin teşkil ettiği bitkisel süslemelerde, tabiattaki bu mucizevî yaratılışların çok iyi gözlemlendiği ve başarıyla kompozisyonlara taşındığı görülür. Türk süsleme sanatlarının kompozisyonlarına tabiatta görülen kavis ve eğriler hakimdir. Arşimed spirali olarak adlandırılan helezonlar, sanatımızda çok eskiden beri kullanılan bir tasarım biçimidir ${ }^{10}$.

\section{İslâmiyet Öncesi Türk Sanatında Helezonlar}

İslâmiyet'ten önceki dönemlerde yaşamış ve önemli eserler bırakmış olan, Hun, Göktürk ve Uygur Devletleri sanatımızın ilk dönem temsilcileridir. Türkler Orta Asya' da yaşamlarını sürdürürken, yaptıkları en basit bir eşyaya dahi sanatlarını yansıtmayı başarmışlardır. Metal, ahşap, deri, taş, seramik, kâğıt, halı, keçe ve kumaş üzerine nakşettikleri desenler geleneksel sanatlarımızın temelini oluşturmuştur. Orta Asya'da Türkler kendilerine özgü bir sanat üslûbuna sahipti. Bozkır sanatı olarak adlandırılan bu sanatta hayvan figürleri ön planda olmasına rağmen bitkisel motiflere her zaman yer veriliyordu. Bitkiler, Türklerin geleneklerinde önemli bir yere sahipti ve bazı ağaç ve çiçeklerin kutsal kabul edildiği biliniyordu. Orta Asya sanatı, Türklerin göçebe yaşayış biçimleri ile din ve inançlarının etkisi altında şekillenmiştir. Çeşitli din ve inançların etkisiyle gelişen kültürleri farklı sanat üslûplarının ortaya çıkmasını sağlamıştır. Sanatlarının gelişiminde bulundukları coğrafyada irtibatta oldukları kültürlerin de etkisi büyüktür.

Orta Asya'da, Türkler milâttan önceki yüzyıllardan itibaren hayvansal figürleri, kullandıkları her türlü eşyaya, farklı malzeme ve tekniklerle aktarımışlardır. Hayvan üslûbundan farklı olarak gelişen bitkisel motiflerin kullanıldığ 1 kıvrık dal üslûbu da Türklerden günümüze ulaşmış eserlerde görülmüştür. Bu bitkisel tarzda geliştirilen figürler, zamanla sanatımızın her alanında temel tezyînat unsurları olarak yer alarak varlıklarını sürdürmüsslerdir ${ }^{11}$. Orta Asya sanatında kıvrık dal üslûbu diye adlandırılan üslûbun temeli helezonlardır. Tabiatta birçok bitkinin görünüşünde yer alan sarmallar bitkiye hareket ve farklılık kazandırır. Geçmişten günümüze ulaşan Türk eserlerinde görülen helezonlar da kompozisyonu sıradanl1k ve durağanlıktan kurtararak canlılık kazandırır.

Asya Hunları tarihte bilinen ilk Türk topluluğu olarak kabul edilmektedir ${ }^{12}$. Hunların yaptığ1 ve milâttan önceki tarihlerden günümüze ulaşmış deri, ahşap, keçe eşyaların yanında, özellikle dokuma eserler geleneksel sanatlarımızın önemli kaynaklarını teşkil eder. Hun sanatında stilize hayvan figürleriyle oluşturulmuş

10 İlhan Özkeçeci, Türk Sanatı'nda Kompozisyon, İstanbul, Plastik Ofset, 2008, s. 13.

11 Celal Esad Arseven, Türk Sanatı, İstanbul, Karaca Matbaas1, 1973, s. 12.

12 Oktay Aslanapa, Türk Sanat, İstanbul, Remzi Kitabevi, 1989, s. 1. 
hayvan üslûbuyla, kıvrık dal üslûbu olarak nitelendirilen bitkisel tasarımlar iç içe görülmektedir. Noin Ula kurganından çıkan yapılış tarihi milâttan önceki yüzyıllara dayanan Hun eserlerinden biri olan işlemeli örtüdeki desenler, geleneksel sanatlarımızdaki helezon sisteminin örneği gibidir (bkz. R. 5). Bu benzerlikler helezonların ayrım noktaları, biçimleri ve dönüş yönlerinden kaynaklanmaktadır. İnsanlığın yeryüzündeki varlığından bu yana kullanılan helezonlar, milâttan önceki yüzyıllardan beri tezyînat amaçlı kullanılmaktadır ve bu örtü günümüze ulaşmış en eski örneklerdendir.

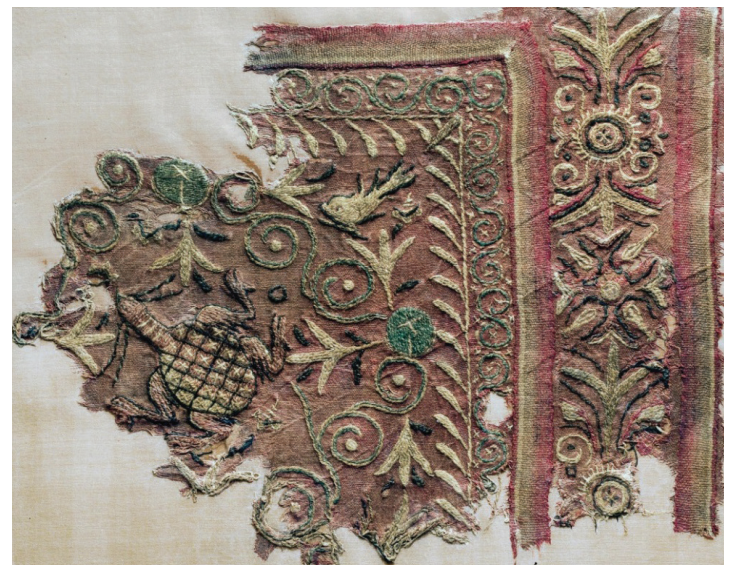

R. 4- Hun Dönemi, Orta Asya, Noin Ula Kurgan1, M. Ö. 1. yüzyıl, İşlemeli Dokuma Örtü.

(https://www.hermitagemuseum.org/wps/portal/hermitage/digital-collection/11.+textiles\%2c+tapestry/430775) (Erişim Tarihi: 23.02.2020)

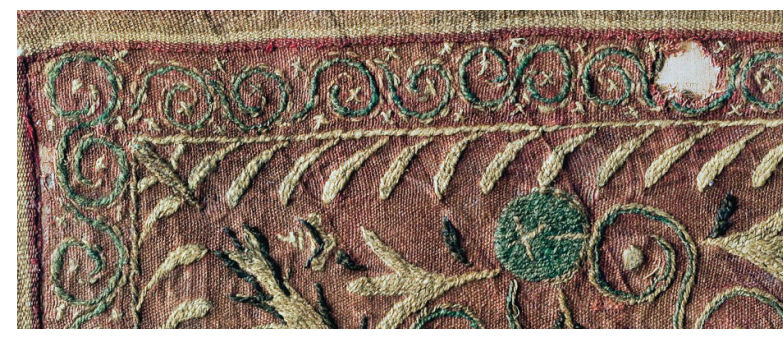

\section{R. 5- Helezonlar (R. 4'ten ayrıntı)}

Eski Türkler, helezonları yaptıkları hemen her desende kullanmışlardır. Hayvansal ve bitkisel betimlemelerde desene canlılık ve hareket sağlayan helezonlar tasarımlara adeta boyut kazandırmıştır. Türkler, yaşamlarının bir parçası olan bitkisel öğeleri, kullandıkları eşyalara da nakşetmişlerdir. Hayvansal figürler ağırlıklı olarak kullanmasına karşılık, çiçek, ağaç ve yaprak motiflerini de kompozisyonla- 
rında ustalıkla kullanmışlardır. Kendine özgü ve eşsiz sanatlarını ilerledikleri bütün bölgelere götürmüşlerdir. Yayıldıkları geniş topraklar ve birçok toplumla olan münasebetleri neticesinde sanatları hızla ilerlemiş ve farklı üslûplar kazanmıştır.

Orta Asya'da yaşamış bir millet olan İskitlerden günümüze ulaşan eserlerde yüksek bir sanat üslûbu dikkat çeker. Orta Asya'da ortak bir coğrafya ve kültür içinde varlığını sürdürmüş olan toplumların sanatlarında benzer noktalar göze çarpar. Milâttan önce İskitler dönemine atfedilen altın gögüslük üzerinde yer alan helezonların şekli ve çiçek ve yaprak motiflerinin dizilişi açısından geleneksel sanatlarımızda kullanılan tasarımlarla çok yakın bir benzerlik göstermektedir (bkz. R. 6). Hayvansal figürlerin ve bitkisel öğelerin birlikte fakat ayrı kısımlarda tasarlandığı eserde helezon sisteminin temele yerleştirildiği görülmektedir. Helezon sisteminin çıkış noktası, ortaya yerleştirilen yaprak motifleridir ve bu nokta yaprakların üstündeki papatya benzeri bir motifle kapatılmıştır. Sağ ve sol olmak üzere iki yöne ayrılır ve simetrik devam eder. Ancak, yaprak ve çiçek motifleri simetrik değildir ve hepsi birbirinden farklıdır.

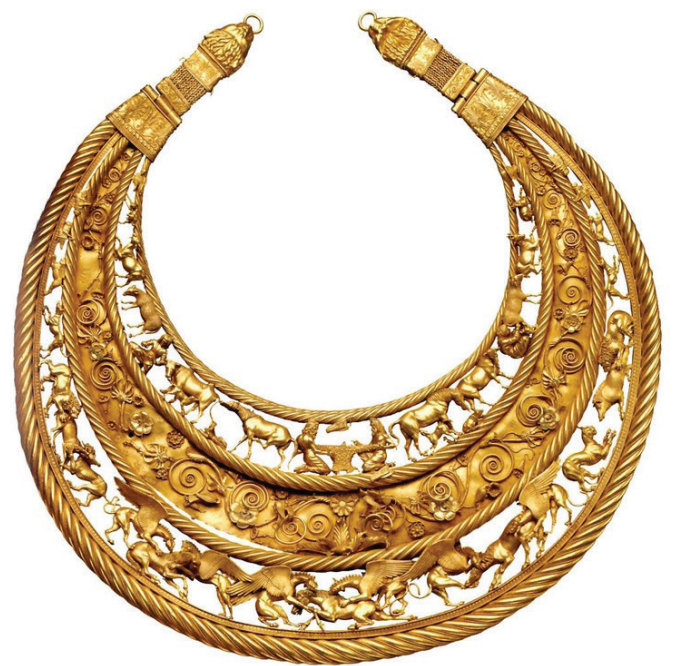

R. 6- İskit Dönemi, Orta Asya, M. Ö. 4. yüzyıl, Altın Göğüslük.

(https://tr.pinterest.com/pin/338544096958946284) (Erişim Tarihi: 23.02.2020)

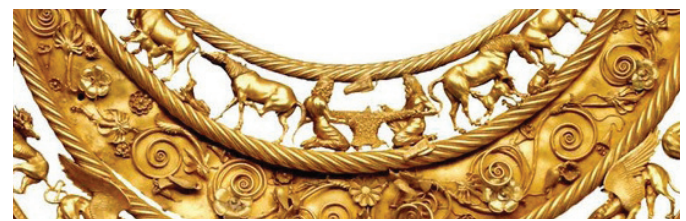

R. 7- Helezonlarla Oluşturulmuş Bitkisel Kompozisyon. (R.6'dan ayrıntı) 
Orta Asya'da varlığını sürdürmüş bir Türk devleti olan Uygurlar zamandan kalma eserler de geleneksel sanatlarımız için büyük önem arz etmektedir. Uygurlar'dan günümüze ulaşmış olan mağara ve mezarlardaki duvar resimleri, el yazmaları, deri, metal, ahşap ve keçe eşyalar üzerindeki desenlerde sanatımızın temelleri yatmaktadır. Bazı tasarımlarda yazı, tezhip ve minyâtürlerin bir arada kullandığı görülmüştür.

Uygurlar dönemine ait bir belge, geleneksel sanatlarımızda kullanılan helezonların yazma eserlerde kullanılan ilk örneklerindendir (bkz. R. 8). Kıvrımlı dalların üzerine yerleştirilen stilize yaprak ve çiçeklerin şekilleri ve yerleştirilme biçimleri itibariyle de geleneksel sanatlarımız için çok önemli bir kaynaktır. Milâttan sonra 8- 9. yüzyıllara ait olduğu düşünülen eserde temele yerleştirilen helezonlar kompozisyona akıcı bir üslûp kazandırmıştır. Tezyînatta kullanılan çiçek motiflerinin, kıvrak dallar üzerine uygun oranlarla resmedildiği anlaşılmaktadır.

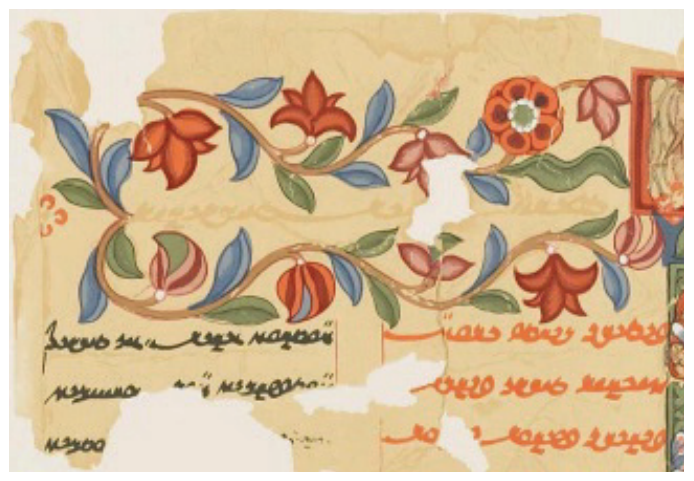

R. 8- Uygurlara Ait Yazma Eser, Bezeklik Turfan Bölgesi, Orta Asya, 8-9. yüzy1llar.

(A. von Le Choc, Chotscho, Berlin, Germany, 1913, s. 5.)

(http://dsr.nii.ac.jp/toyobunko/viewer/index.html?pages=LFc-42/V-1\&pos=41\&lang=en)

Orta Asya Türk sanatından günümüze ulaşmış eserler incelendiğinde geometrik ve durağan formlara pek rastlanmaz. Daha çok kıvrımlı ve hareketli desenler görülür. Kompozisyonlar canlı ve sonsuzluk hissi uyandıran helezonlardan oluşmuşlardır. Bu formlar daha sonraları İslâm sanatlarının biçimlenmesinde etkili olmuş ve geleneksel sanatlarımızın da temelini oluşturmuşlardır.

\section{İslâmiyet Sonrası Türk Sanatında Helezonlar}

Türkler İslâmiyeti kabul ettikten sonra, kendi kültürlerini İslâm inanciyla birleştirmişlerdir. Farklı medeniyetlerin sanatsal birikimlerinden etkilenmiş ve bir çok toplumu da eşsiz sanat anlayışlarıyla yönlendirmişlerdir. Türk sanatı, Orta Asya'dan gelen sanat üslûplarıyla ilerleyerek, İslâm medeniyetine kazandırdığı birbirinden değerli eserlerle dünya sanat tarihinde önemli bir yer edinmiştir. 
İslâm sanatında, en küçük bir eşyada ya da görkemli bir mimarî eserde aynı incelik ve üslûp birliği göze çarpar. Orta Asya sanatı, Türk İslâm sanatlarının esin kaynağı olmuştur. Milâttan önceki yüzyıllardan beri kullanılan motifler, yeni bir bakış açısı ile yorumlanarak farklı kompozisyonlar üretilmiştir.

Milâttan önceki dönemlerden süregelen gelen hayvan figürleri İslâmiyet'in kabulüyle soyutlaştırılma yoluna gidilmiş, zamanla bu hayvansal üslûptan tamamen uzaklaşılmıştır. Bitkisel motiflerden de bazıları kökeni belli olmayacak şekilde stilize edilirken, birçoğunun tabiattaki benzerine bağl1 kalarak kompozisyonlarda yer aldığı görülmüştür. İslâm sanatlarında mimarî ve tezyînat birbirini tamamlayan unsurlar olarak kullanılmışlardır. Geleneksel sanatlarımız, kendimize ait değerlerin yanında, birçok medeniyetin kültür öğelerini de içeren bir birikim sonucu oluşmuştur. Tezhip, cilt, ebru, kalem işi, çini, mimarî, ahşap, taş, cam, maden sanatları geleneksel sanatlarımızdandır. Helezon formları İslâmiyet sonrası da kompozisyonların alt yapısını oluşturmaya devam etmiştir.

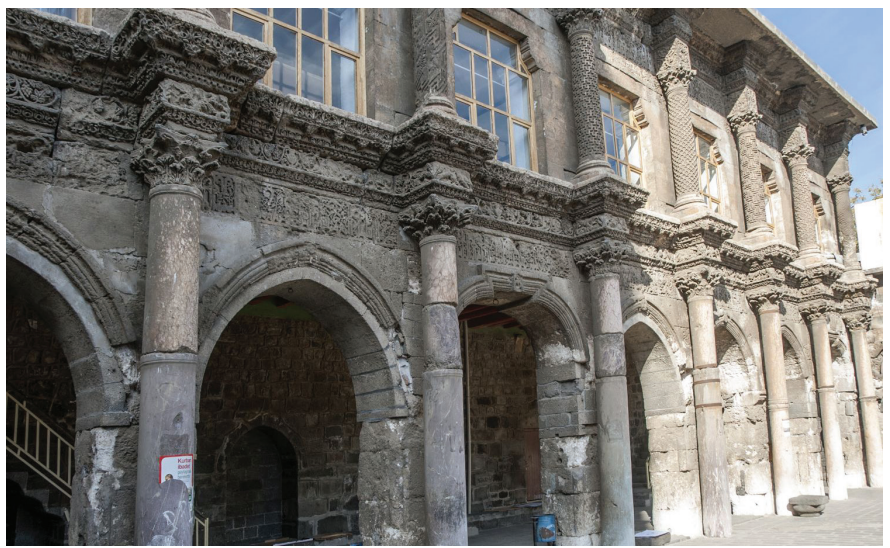

R. 9- Diyarbakır Ulu Camii, 1091, Büyük Selçuklu Hükümdarı Melikşah Dönemi, Diyarbakır, Türkiye.

(https://archnet.org/sites/1927/media_contents/129157) (Erişim Tarihi: 24.02.2020)

İslâmiyet'in kabulü sonrasında geleneksel sanatlarımızın örneklerini Karahanlılar, Gazneliler, Büyük Selçuklular, Anadolu Selçukluları, Beylikler ve Osmanlı Devleti'nden günümüze ulaşmış eserlerde görmek mümkündür. Osmanlı zamanında 16. yüzyılda, altın çağını yaşayan geleneksel sanatlarımız bu dönemde olgunlaşmış ve günümüze dek ulaşmıştır.

İslâmiyet sonrasında hayvan ve insan tasvirlerinden uzaklaşılmış, geometrik ve bitkisel kompozisyonlar önem kazanmıştır. Mimarî yapılar, el yazması eserler, savaş malzemeleri, günlük kullanım eşyalarında çiçek, meyve, ağaç ve yaprak figürleriyle tezyînatlar ağırlıktadır. Helezonlar bitkisel kompozisyonların vazgeçilmez öğesi 
olarak yer almaya devam etmişlerdir. İslâmiyet'in kabulüyle birlikte, bitkisel motif çeşitliliği artmış, helezonlar daha zarif ve daha estetik bir görünüm kazanmışlardır.

Selçuklular birçok sanat alanında önemli eserler verdikleri gibi, mimarî alanında da kalıcı ve değerli yapılar bırakmışlardır. Bunlardan biri de Diyarbakır Ulu Camii' dir. İnce bir işçilikle, adeta dantel gibi oluşturulmuş kompozisyonun temeline oturtulan helezonlar, belli noktalara yerleştirilen asma yaprakları ve üzüm motifleriyle tamamlanmıştır. Helezonlar ince ve sarmal dallar biçiminde zarif bir üslûpla tezyîn edilmiştir (bkz. R. 10).

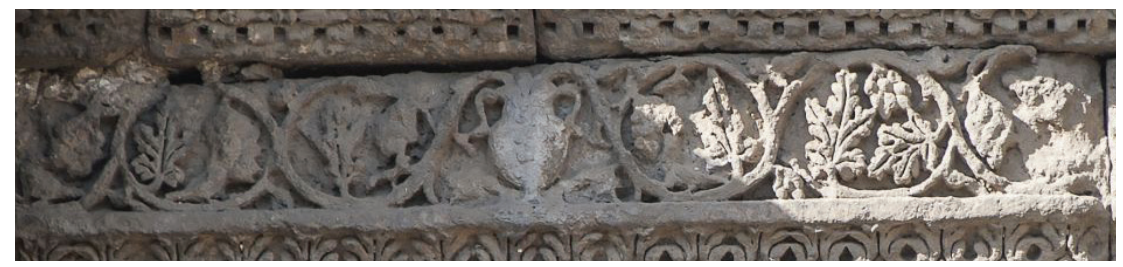

R. 10- R. 9'dan Ayrıntı. Taş İşçilikte Bitkisel Motiflerle Kullanılan Helezonlar (https://archnet.org/sites/1927/media_contents/129183) (Erişim Tarihi: 24.02.2020)

Anadolu Selçuklu dönemine ait Varka ile Gülşah Mesnevîsi Türk İslâm sanatları için önemli bir kaynaktır. İçerisindeki resimlerin renk ve kompozisyon teknikleri açısından minyâtür sanatımıza katkıları büyüktür. Eserde küçük yaprak motifleriyle kaplanmış helezonlar şeklinde kıvrımlı çiçek dalları görülmektedir (bkz. R. 11) Tomurcuk şeklinde tasarlanmış çiçek motifleri orantılı bir biçimde helezonlar üzerine yerleştirilmiştir.
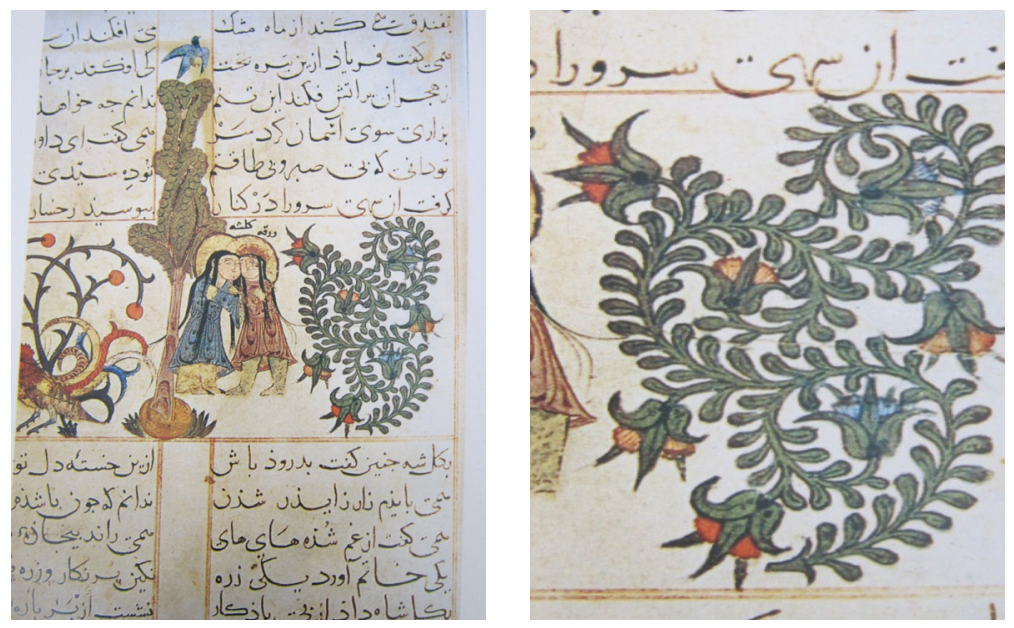

R. 11- TSMK, H.841, 33b, Varka ile Gülşah, Anadolu Selçuklu Dönemi, 13. yüzy1l.

(Sıtkı Fırat, Selçuklu Sanatı, T. C. Kültür Bakanlığı Yayınları, Ankara 1996, s. 48.) 
Fatih dönemi eserlerinden oluşan Mecmaü'l Acaîb albümünde yer alan Baba Nakkaş üslûbundaki tezyînat, geleneksel sanatlarımızdan biri olan tezhip sanatımızın en güzel örneklerindendir. Daire formunda tasarlanan kompozisyondaki helezonlar iki bölüm halinde tasarlanmışlardır. Bütündeki uyum kompozisyona estetik bir görümüm kazandırmıştır. Stilize yaprak ve çiçek motifleri bitki dallarına farklı boyutlarda, ahenkli bir biçimde yerleştirilmişlerdir. Kıvrımlı dallarla akıcı bir üslûp oluşturulmuştur (bkz. R. 12).

Topkapı Sarayı Müzesi’ndeki Fatih dönemine ait bulunan çeşmede de siyah zemin üzerine altın varakla işlenmiş desenin helezonlardan oluşturulduğu görülmektedir (bkz. R-13). Simetrik biçimde uygulanan desen bitkisel motiflerden oluşmaktadır. Kompozisyonun temelini oluşturan helezonlardaki kıvraklık ve uyum dikkat çekicidir.

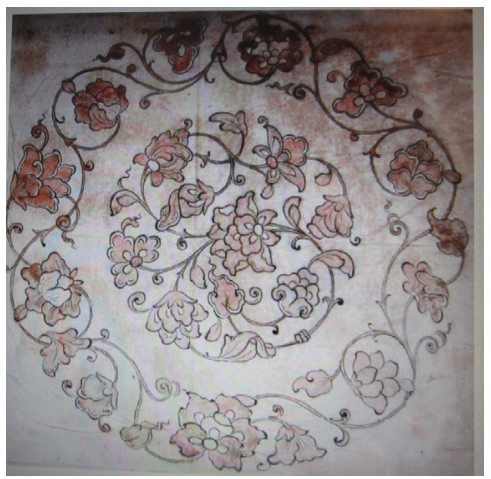

R. 12- İ̈K, F. 1423, Mecmaü’l Acaîb Albümünden, Baba Nakkaş Üslûbu Tasarım, 15. yüzyıl.
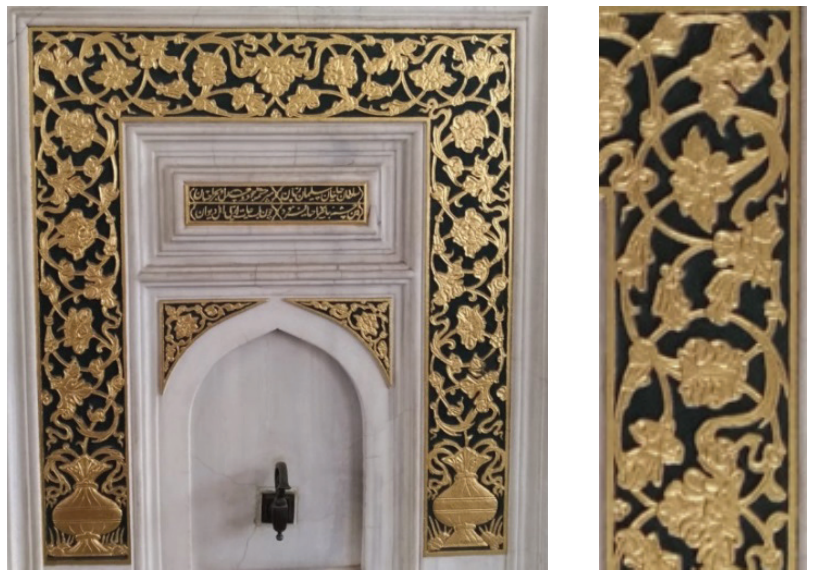

R. 13- TSM Arz Odası Giriş Kapısı Yanındaki Çeşme, 15. yüzyıl.

(F. H. Nur Özsoy 2018) 


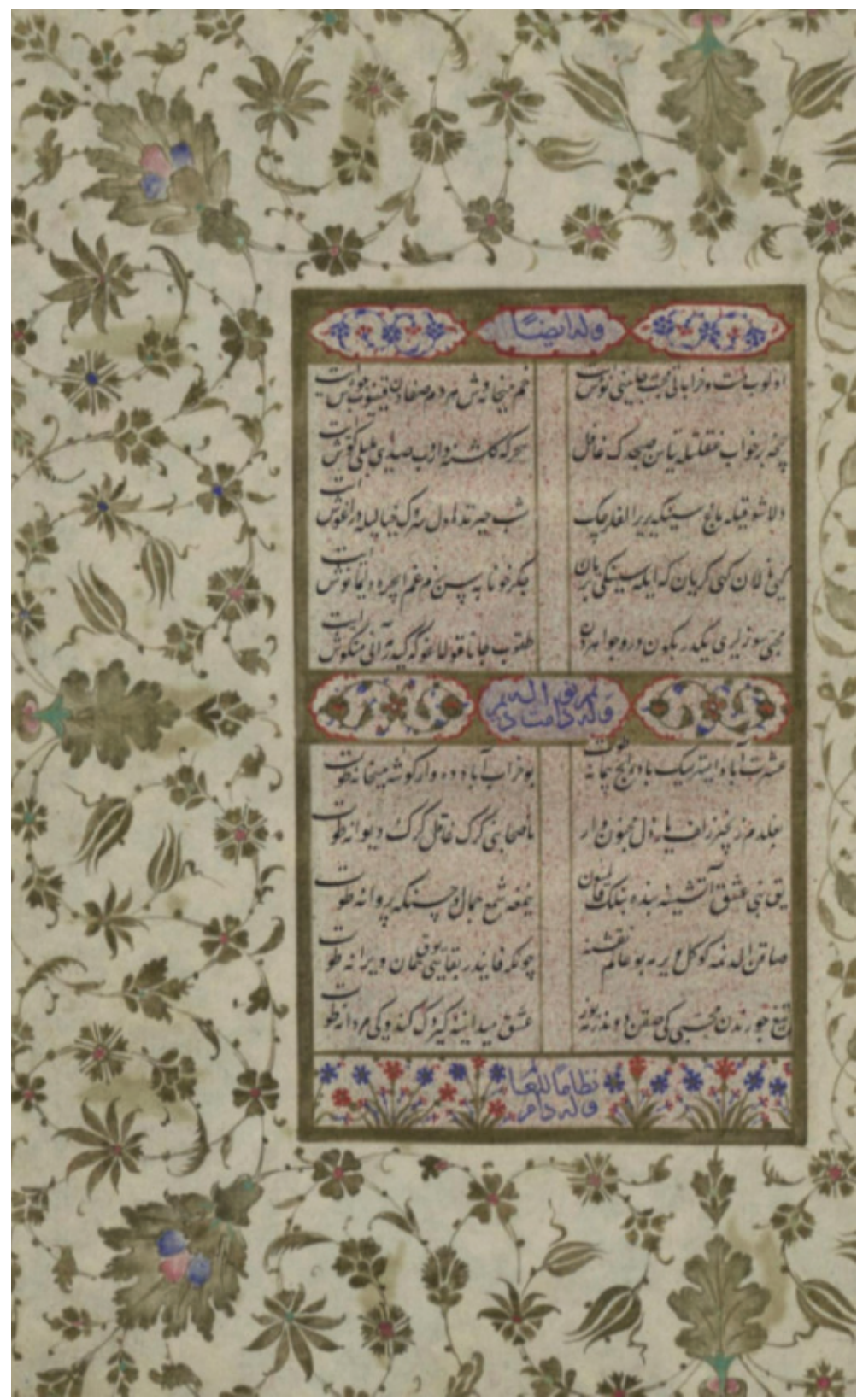

R. 14- SK BB 12968, Muhibbî Divan1, Osmanlı, 16. yüzyıl.

Geleneksel sanatlarımız 16. yüzyıl Osmanlı döneminde altın çağlarını yaşamışlardır. Bu dönemdeki kompozisyonlarda renk, işçilik, zerafet ve çeşitlilik en 
olgun seviyesindedir. Farklı üslûpların ve tekniklerin uygulandığı bu klâsik devir, geleneksel sanatlarımızın en ihtişamlı zamanıdır.

Klâsik dönem eserlerimizden olan Muhibbî Divanı'ndaki bir sayfada helezonların ustalıkla kullanıldığı ve stilize çiçek motiflerinin sarmal dallar üzerine mükemmel oranlarla yerleştirildiği görülmektedir (bkz. R.14). Motifler, helezonların gidiş yönüne doğru yerleştirilmiştir. Sarmal kıvrımlar motiflerin merkezinden geçmektedir. Helezonların boyutları, motiflerin birbirleriyle uyumu, kompozisyon içindeki dağılışları sanatçıların ustalık, bilgi ve inceliklerini yansıtmaktadır. Muhibbî Divanı, bitkisel tezyînatın en güzel öneklerini barındırmaktadır.

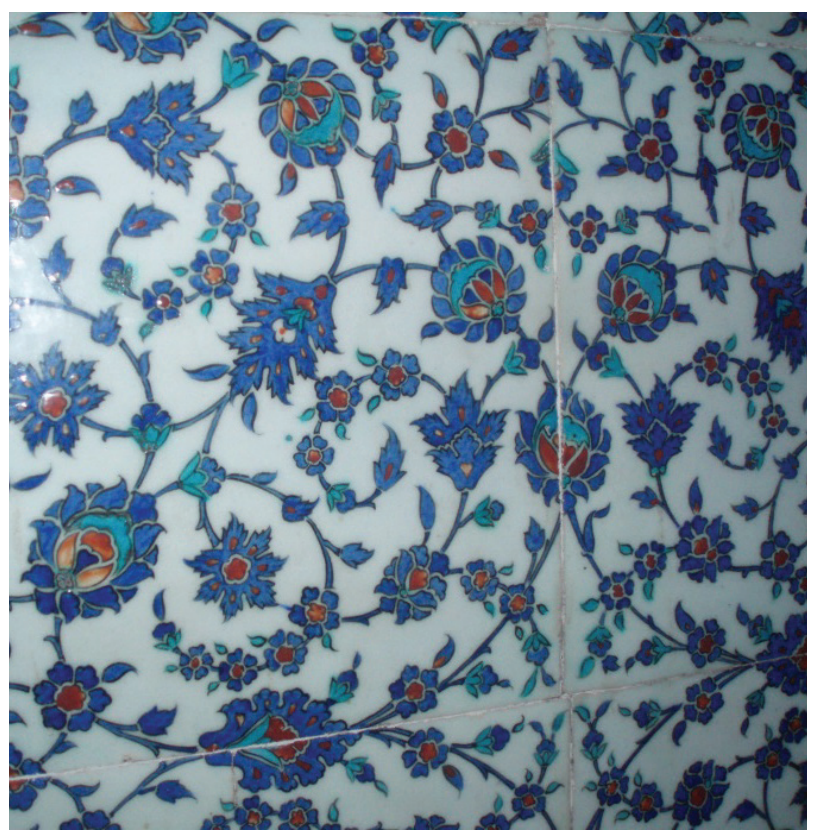

R. 15-Rüstem Paşa Camii Çini Pano, 1563 tarihli. (F. H. Nur Özsoy 2010)

16. yüzyıl, klâsik dönemde yapılmış olan Rüstem Paşa Camii çini sanatımızın en güzel örneklerini içeren eserlerimizden biridir. Çini panoda görülen tezyînatta, kıvrımların muntazamlığı, motiflerin birbirleriyle ve kompozisyonun bütünüyle uyumu göze çarpar ( bkz. R. 15). Helezonların ayrım noktalarına yerleştirilen büyüklü, küçüklü motiflerle mükemmel bir görünüm elde edilmiştir. Desendeki boşluk doluluk oranları da kusursuzdur. 


\section{Sonuç}

Mikroskobik bir canlının yapısından, uzay boşluğundaki bir galaxinin görünüşüne kadar her yerde karşımıza çıkan helezonlar, sonsuzluk ve canlılığı temsil ederler. Kainatın yaratılışındaki oran sistemine dayanan helezonların sanat alanında kullanımları insanlığın tarihi kadar eskidir. Kökeni Orta Asya'da dayanan geleneksel sanatlarımızın temeli bitkisel motiflerdir. Bitkisel tezyînatın temel taşını ise helezonlardan oluşur. Geleneksel sanatlarımızdaki kompozisyonlarda bütünlük ve denge çok önemlidir ve sanatçılar bunu oran ve orantı sistemi üzerine kurulu helezonlarla sağlamışlardır. Helezonlar, temel taşı vazifesi görerek, kompozisyonlara canlılık, uyum, ritim ve hareket sağlarlar. Türk sanatındaki en eski örnekleri milâttan önceki yüzyıllara dayanan helezonların İslâmiyet'ten önceki dönemlerde olduğu gibi, İslâmiyet sonrasında da önemini koruduğunu ve bu üslûbun gelişerek, ilerlediği görülmüştür. Geleneksel sanatlarımızda yüzyıllardır kullanılan helezonlar, sanatçıların güçlü gözlem gücü, sanatsal birikim, sabır ve yetenekleriyle oluşturulmuşlardır ve bugün de tezyînatlarda kullanılmaya devam etmektedir. Helezonların tarihçesinin aydınlatılmasının, sanatçılara yeni tasarımları için ilham kaynăğ olması ümit edilmektedir. 


\section{Kaynakça}

Arseven, Celal Esad, Türk Sanatı, İstanbul, Karaca Matbaası, 1973.

Aslanapa, Oktay, Türk Sanatı, İstanbul, Remzi Kitabevi, 1989.

Birol, İnci, Türk Tezyinî Sanatlarında Desen Tasarımı, İstanbul, Seçil Ofset, 2009.

Choc, A. von Le, Chotscho, Berlin, Germany, 1913.

Çiftçi, Meryem, "XVI. Yüzyıl Kuran-1 Kerîm Sayfa Düzenleri Açısından Türk Tezhip Sanatında Altın Oran İncelemesi”, (Yayımlanmamış Yüksek Lisans Tezi), FSM Vakıf Üniversitesi Lisansüstü Eğitim Enstitüsü Geleneksel Türk Sanatları, İstanbul, 2019.

Derman, Fatma Çiçek, "Tezhip Sanatı”, İslâm Sanatları Tarihi, Eskişehir, Anadolu Üniversitesi Yayınları, 2012.

Fırat, Sıtkı, Selçuklu Sanatı, Ankara, T. C. Kültür Bakanlığı Yayınları, 1996.

Keskiner, Cahide, Türk Süsleme Sanatlarında Stilize Çiçekler, Ankara, T.C. Kültür Bakanlığı, 2002.

Özkeçeci, İlhan-Özkeçeci, Şule Bilge, Türk Sanatında Tezhip, İstanbul, Seçil Ofset, 2007.

Özkeçeci, İlhan, Türk Sanatı'nda Kompozisyon, İstanbul, Plastik Ofset, 2008.

Taşkale, Faruk, “Tezhip Sanatının Kullanım Alanları”, (Yayımlanmamış Sanatta Yeterlik Tezi), Mimar Sinan Üniversitesi Sosyal Bilimler Enstitüsü Geleneksel Türk El Sanatları Anasanat Dalı Tezhip Program1, İstanbul, 1994.

Tekkanat Nihal, “Altın Oran'ın Kaynakları ve Sanat'a Yansıması”, (Yayımlanmamış Yüksek Lisans Tezi), Akdeniz Üniversitesi Sosyal Bilimler Enstitüsü Grafik Anabilim Dalı, Antalya, 2006.

https://archnet.org/

http://dsr.nii.ac.jp/toyobunko

https://www.etimolojiturkce.com

https://www.hermitagemuseum.org

https://tr.pinterest.com

https://tr.wikipedia.org 